\title{
Techniques of orchard establishment in arid and semi-arid regions
}

\section{DS Mishra, Sanjay Singh, AK Singh, VV Appa Rao \& DK Sarolia}

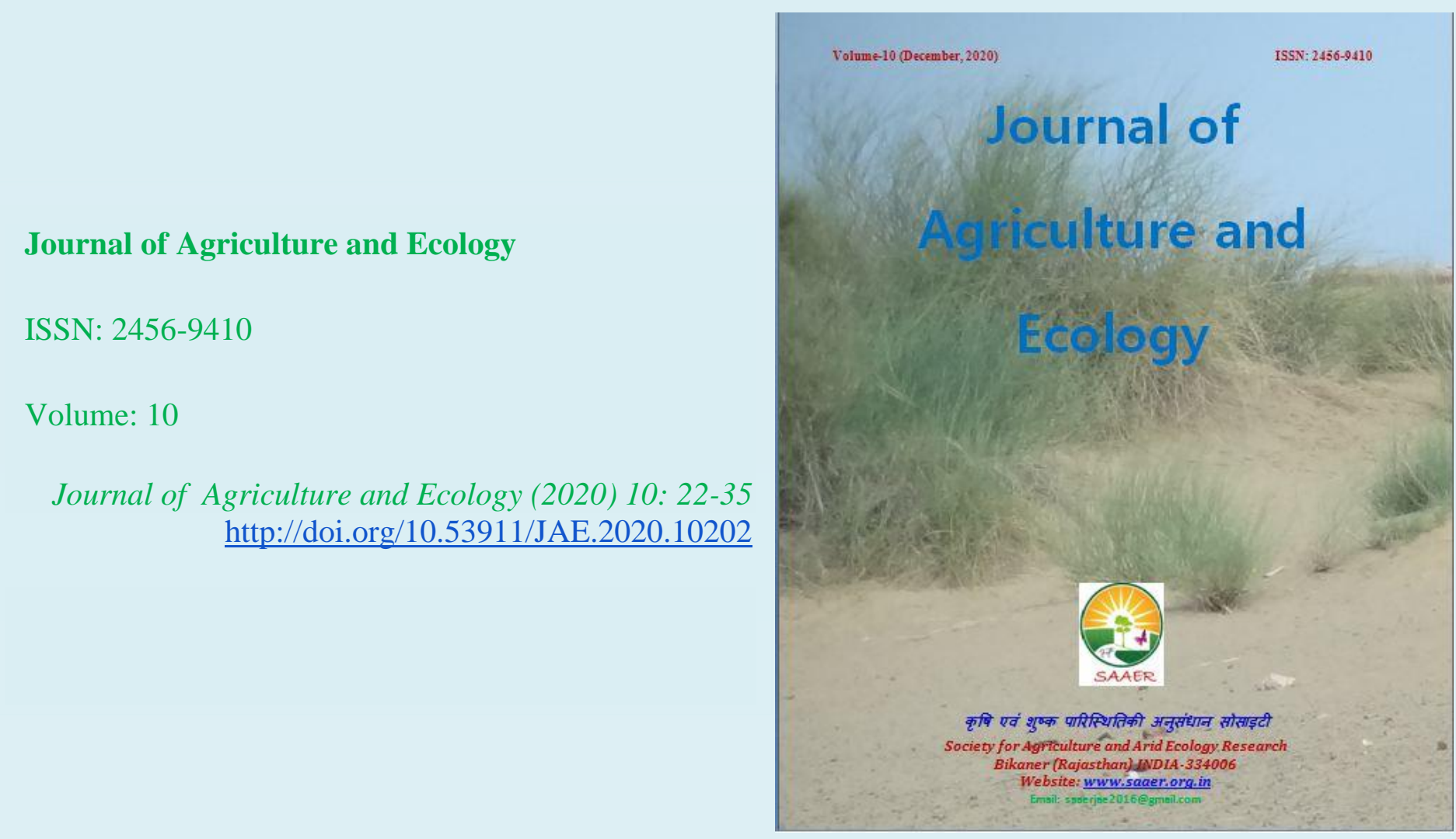




\title{
Techniques of orchard establishment in arid and semi-arid regions
}

\author{
DS Mishra \, Sanjay Singh, AK Singh, VV Appa Rao \& DK Sarolia* \\ Central Horticultural Experiment Station (ICAR-CIAH, Bikaner), Vejalpur, Panchmahals, (Godhra), \\ Gujarat-389340 \\ *ICAR-Central Institute for Arid Horticulture, Bikaner \\ $\square$ Corresponding author: DK Sarolia, E-mail: deephorti@gmail.com
}

\section{Article Info \\ Article history \\ Received: 25 September 2020 \\ Accepted: 25 November 2020 \\ Available online: 31 December 2020}

Key Words: Production system in arid/semi arid, orchard establishment, techniques of planting.

\begin{abstract}
Orchard establishment is a long term investment, so careful planning and proper techniques of planting are prerequisites. There are two ways of orchards arranged i.e., traditional and modern or high density planting. In arid and semi arid conditions its more matter in context of location/site, crops $\&$ its varieties selection as well as techniques of planting and after care over other climatic regions. This region mostly having fragile ecosystem (unpredictable weather, limited and erratic rainfall) and poor in soil organic matter and available nutrients as well as other conditions for normal growth and development of the plant. Most suitable arid fruit crops are ber, ker, lasoda, pomegranate, fig, date palm, karonda, phalsa etc or having xerophytic adaptation, similarly semi-arid region potential crops are sweet orange, lime, jamun, khirni, bael, guava, aonla, custard apple, tamarind, mahua, chironji etc or possessing phonological adjustment (critical growth stage completion in optimum moisture available season). Apart from adaptations proper care and management techniques are require for sustainable/ potential production of these fruit crops in this region.
\end{abstract}

Copyright (C2020 Mishra et al., This is an open access article published under the terms of the Creative Commons Attribution License, which permits unrestricted use, distribution, and reproduction in any medium, provided the original work is properly cited.

Preferred citation: Mishra DS, Singh S, AK Singh, VV Appa Rao \& DK Sarolia. 2020. Techniques of orchard establishment in arid and semi-arid regions. Journal of Agriculture and Ecology, 10: 22-35; http://doi.org/10.53911/JAE.2020.10202.

\section{Introduction}

The earth's surface represents varied type land forms such as humid, arid, coastal and glaciated. Each type of landform exhibits a particular group of physical processes. Such processes are having significance for the humankind in view of their economic activities. However, drought and desertification is a common process and phenomenon in arid and semi-arid areas is a matter of great concern to raise crops in such a fragile ecosystem. Generally arid and semiarid regions are characterized by unpredictable weather, limited and erratic rainfall, nutrient poor soils, and home to a sizable global population (Saroj, 2018). The semi-arid zone can support rain-fed agriculture with more or less sustained levels of production. Annual precipitation varies from 300-600 to $700-800$ $\mathrm{mm}$ in these areas. In India semi-arid zone 
occupy nearly $37 \%$ of total geographical area which is spread over in Maharashtra ((19\%), Karnataka (15\%) Andhra (15\%), Rajasthan (13\%), Tamil Nadu (10.0\%), Gujarat (9.50\%), UYP (7.0\%) and Madhya Pradesh (6.0\%) (Singh et al., 2018). However, the arid zones are so diverse in terms of their landforms, soil, fauna, flora, water bodies and human activities and term arid implies prolonged dryness, and is used with respect to the climate and the land below it. In such regions the ability to produce agricultural crops is restricted. Usually on arid lands the potential evaporation of water from the land exceeds the rainfall. The land may be characterized according to the degree of aridity as dry forest, or brush land, grassland or desert. In India, arid regions are spread over 39.54 million hectare which includes hot arid regions (31.71 mha) distributed mainly in Rajasthan, Gujarat, Andhra Pradesh, Punjab, Haryana and southern peninsular regions and 7.38 million hectare as cold arid zone in Jammu and Kashmir and Himachal Pradesh (Saroj, 2018a). Both arid and semi-arid regions of country constitute $53.40 \%$ of total geographical area. These regions pose biophysical constraints for crop production owing to poor soil conditions, meager water availability for irrigation, extremely low or high temperatures, hot and dry winds, high solar radiation and scanty rainfall leading low moisture index and high potential evapotranspiration (Nath et al. 2008, Samadia \& Haldhar 2017).

Nevertheless, these environmental conditions offers great opportunity for production of some hardy fruit species which are a rich source of antioxidants and other health promoting phytochemicals (Mishra et al. 2016; Tiwari et al. 2018) and development of high quality produce in a number of fruit crops (Sharma et al. 2013) such as date palm (Phoenix dactylifera L.), ber (Ziziphus mauritiana Lam.), aonla (Emblica officinalis Gaertn.), bael (Aegle marmelos (L.) Correa.), pomegranate (Punica granatum L.), kinnow (Citrus nobalis Tan. x Citrus deliciosa Tan.) and lasoda (Cordia myxa G. Forst.). The recent awareness regarding the potential of these ecologically fragile lands for production of quality produce has not only opened up scope for providing nutritional security for the people of these regions, but also for bringing in new areas to increase horticultural production (More et al. 2012).

Table 1. Global scenario of different dry-lands

\begin{tabular}{lccccc}
\hline $\begin{array}{l}\text { Dry-land } \\
\text { types }\end{array}$ & Aridity index & $\begin{array}{c}\text { Global area } \\
(\boldsymbol{\%})\end{array}$ & $\begin{array}{c}\text { Global } \\
\text { population } \\
(\boldsymbol{\%})\end{array}$ & $\begin{array}{c}\text { Rangeland } \\
\mathbf{( \% )}\end{array}$ & $\begin{array}{c}\text { Cultivated } \\
(\boldsymbol{\%})\end{array}$ \\
\hline Hyper arid & $\leq 0.05$ & 6.60 & 1.70 & 97.0 & 3.0 \\
Arid & $0.05-0.20$ & 10.60 & 4.10 & 87.0 & 7.0 \\
Semi-arid & $0.20-0.50$ & 15.20 & 14.40 & 54.0 & 35.0 \\
Sub-humid & $0.50-0.65$ & 8.70 & 15.30 & 34.0 & 47.0 \\
Total & & 41.30 & 35.50 & 65.0 & 25.0 \\
\hline
\end{tabular}

(Source: UN, Environ Management Group 2011) 
Table 2. Mean vapour pressure, relative humidity and rainfall in different ecosystems in India

\begin{tabular}{lcccc}
\hline Parameters & Month & Arid & Semi-arid & Sub-humid \\
\hline Vapour pressure (mb) & July & 28.70 & 28.70 & 27.10 \\
& August & 28.10 & 28.70 & 27.0 \\
Relative humidity (\%) & July & 65.0 & 69.0 & 79.0 \\
& August & 70.0 & 75.0 & 82.0 \\
Annual rainfall (mm) & - & 310.0 & 841.0 & 1209.0 \\
\hline
\end{tabular}

(Source: Nath et al. 2008)

Major constraints of fruit-culture in arid and semi-arid regions

Water: In arid and semi-arid regions, the rainfall is significantly less than the potential evapo-transpiration throughout the year. Therefore, successful crop production depends on stored soil water in addition to rainfall. Plants adapt to aridity by various mechanisms like deep or extensive root systems (aonla, ber) which have the ability to draw water from a wide area, coincidence of vegetative growth and reproductive phase with the period of maximum moisture availability (ber, aonla, guava, pomegranate, custard apple, sour lime), plants storing water in their tissues and release it very slowly (cactus pear), plant species protected from water loss by wax (fig, phalsa) etc. Fruit plants in arid and semi-arid regions may have any or a combination of such adaptive mechanisms. Irrigation sources like rivers, lakes and wells in these regions may have quality issue due to the presence of excess minerals. Irrigation with such water may promote the accumulation of salts in the soil resulting in alkalinity or salinity, thus, limit the crop production. In all arid regions a major challenge is to manage water appropriately. The purpose of such management is to obtain water, to conserve it, to use it efficiently, and to avoid damage to the soil.

Heat and Wind: The major impact of heat and wind are the enhanced rate of evaporation, and resultantly increases the effects of aridity. This can be tackled by modifying the microclimate. The detrimental effects of wind can be reduced by planting lines of perennial trees perpendicular to the direction of prevailing winds known as windbreaks like Casuarina, jamun, mulberry, aonla and bael. As a general rule, a windbreak is effective over an area 2.5 times the height of the tree. Heat is received principally from the sun radiation which can be reduced by shading. However, shading also reduces the yields of plants. A light shade such as that below aonla planting or a protective screen or lathwork can be useful in reducing heat and retaining moisture, with only a minimum loss of yield.

Soils: Soils of the arid and semi-arid regions are highly variable, as they are in any climate. The soils of arid region are very poor in availability of nutrients and water holding capacity. The soils of the north-western arid region of India are desert soils and grey brown soils of the Order Aridisols with light texture. Most of arid areas (about 64.6\%) are sandy, where the soils often contain only about 3.2- 
4.0\% clay and 1.4-1.8\% silt. Besides this, about $5.9 \%$ area is covered by soils having hard pan, $5.6 \%$ is under hills and pediments, $6.8 \%$ area is alluvial dunes and $1.6 \%$ is sierozems extending from the soils of Haryana and the Punjab. In the peninsular India, a considerable part of arid region has red sandy soil and some parts have mixed black soils. The soils are poor in organic matter having $0.03 \%$ organic carbon in bare sand dunes to $0.1 \%$ in the stabilized dunes. Soils are generally rich in total potassium and boron, but are low in nitrogen, phosphorus and micronutrients such as copper, zinc and iron. The soils often have high salinity. Due to low rainfall and reduced plant growth, organic material is produced slowly. The amount of organic material in the soil, and thus the potential fertility, is likely to be high in semiarid zones, low in deserts. Because of low rainfall in desert soils, minerals derived from breakdown of rocks are not leached from the soil. In some cases where the soil is periodically flooded or irrigated the soil might be saline as well. Such soils support few crops. Plants having ability to adapt to shallow soils, rocky, gravelly, and undulating wastelands like pomegranate, custard apple, aonla, bael can be tried (Pareek \& Sharma 1991).

Table 3. Relative salt tolerance of fruit crops

\begin{tabular}{lccc}
\hline High salt tolerance & Medium salt tolerance & \multicolumn{2}{c}{ Low salt tolerance } \\
$\left(\mathrm{EC}_{\mathrm{e}} \times 10^{3}=18^{(2)}\right)$ & $\left(\mathrm{EC}_{\mathrm{e}} \times 10^{3}=10\right)$ & \multicolumn{2}{c}{$\left(\mathrm{EC}_{\mathrm{e}} \times 10^{3}=5\right)$} \\
Date Palm & Pomegranate & Orange & Apricot \\
& Fig & Grapefruit & Pear \\
& Olive & Lemon & Strawberry \\
& Grape & Apple & Plum
\end{tabular}

The numbers following $\mathrm{EC}_{\mathrm{e}} \times 10^{3}$ are the electrical conductivity values of the saturation extracts in millimhos per $\mathrm{cm}$ at $25^{\circ} \mathrm{C}$ associated with a $50 \%$ decrease in yield.

(Source: Richard et al. 1954)

\section{Selection of fruit crops and varieties}

The environmental conditions of arid region are very harsh for sustainability of plants hence; selection of a plant species for such region is important for growth and production. The selection of fruit crops and cultivars for different situations will have to be done at utmost care, because these plantations will remain productive for 20 to 60 years, depending upon the crop selected and once selected wrong cannot be rectified easily. In arid and semi-arid regions, commercial fruit production requires special technologies regarding selection of crop, orchard establishment and efficient management of soil moisture regime. Therefore, following factors should be taken into consideration while selecting fruit crops for arid and semi arid regions:

1. Avoidance or adaptive mechanisms against drought e.g. deep root system as in ber, aonla, jamun, wood apple, manila tamarind etc.

2. Summer dormancy as in ber, mulberry, karonda, custard apple for tolerance to high temperature or attainment of summer dormancy after pollination and fertilization as in aonla fruits. 
3. High water holding capacity in leaf cells as in fig and cactus pear.

4. Maximum vegetative and reproductive growth of plant coinciding with the monsoon period, for example ber, aonla, karonda, custard apple.

5. Amenability of the plants for such coincidence by cultural manipulations through bahar treatments (pomegranate, acid lime, sweet orange, guava).

6. In addition to this, they must have, reduced leaf area (e.g. Indian gooseberry, tamarind), leaf surface having sunken stomata, thick cuticle, wax coating and pubescence (fig, ber, phalsa, tamarind), and ability to adapt to shallow soils, rocky, gravelly, and undulating wastelands (pomegranate, aonla, bael).

7. Fruit crops must have tolerance to salinity and saline irrigation water which are common features of these areas e.g. aonla, pomegranate, karonda.

Varieties selected for different fruit crops in arid and semi-aridconditions should be short duration i.e. early maturing varieties, so that they can complete their fruiting period in shortest possible time to evade drought conditions (Table 4). Besides they also have tolerance to drought and salinity.

Table 4. Promising varieties of fruit crops for cultivation in semi-arid and arid regions

\begin{tabular}{|c|c|}
\hline Crops & Varieties \\
\hline Ber & $\begin{array}{c}\text { Gola, Seb, Reshmi, Umran, Mundia, Kaithali, Banarasi Kadaka, Thar } \\
\text { Bhubharaj, Thar Sevika, Goma Kirti, Thar Malti }\end{array}$ \\
\hline Bael & $\begin{array}{l}\text { NB-5, NB-7, NB 9, Pant Aparna, Pant Sujata, Pant Shivani, CISH B-1, CISH } \\
\text { B-2, Goma Yashi, Thar Divya, Thar Neelkanth, Thar Srishti }\end{array}$ \\
\hline Pomegranate & Bhagwa, Super Bhagwa, Ganesh, Jalor seedless, G-137, Mridula, Phule Arakta \\
\hline Lasoda & Thar Bold, Maru Samridhi, Karan Lasoda \\
\hline Aonla & $\begin{array}{c}\text { NA-7, NA-6, NA-10, Kanchan, Krishna, Balwant, Laxmi-52, Chakkaiya, Goma } \\
\text { Ashwarya }\end{array}$ \\
\hline Sweet orange & Sathgudi, Blood Red Malta, Mosambi, Pineapple, Valencia \\
\hline Lime & Kagzi, Vikram, Phule Sharbati, Pusa Round, Pramalini, Sai Sharbati \\
\hline Custard apple & $\begin{array}{c}\text { Arka Sahan, Balanagar, Mammoth, Island, Gem, Red Sitaphal, APK (Ca)-1, } \\
\text { Phule Janki, Phule Purander }\end{array}$ \\
\hline Guava & $\begin{array}{c}\text { Allahabad Safeda, L-49, Kohir Safed, Safed Jam, Chittidar, Lalit, Shweta, Hisar } \\
\text { Safeda, Hisar Surkha, Burfkhan genotype }\end{array}$ \\
\hline Jamun & Goma Priyanka, Paras, Thar Kranti, Jamvant \\
\hline Date palm & Halawy, Barhee, Medjool, Shamran, Khuneizi, Khadrawy, Zahidi, ADP-1 \\
\hline Sapota & Kalipatti, Cricket Ball, \\
\hline Fig & Poona Fig, Dianna, Dinkar, Conadria, Excel, Chalisgaon, Black Ischia \\
\hline Mango & Banglora, Kesar, Rajapuri, Bombay Green, Dashehari, Vanraj \\
\hline Tamarind & PKM 1, Pratisthan, Yogeshwari, Goma Prateek \\
\hline
\end{tabular}

While selecting the planting material

following point must be considered 
Planting material should be vigorous, true to type, derived from healthy progeny trees.

$\checkmark$ Cultivars should be well adapted to a particular area with high yield and quality.

$\checkmark$ Only younger planting material should be chosen because of higher establishment.

$\checkmark$ Very high budded or grafted plants prone to wind damage should be avoided.

$\checkmark$ The planting materials should be procured from genuine nurseries.

\section{Orchard Establishment}

Orchard establishment is a long term investment and requires thorough planning starting from site selection, spacing, selection of species and varieties, quality of planting material, planting design and density. While site selection, important associated factors are local climate, and availability of quality water, availability of labour, proximity to the market, transport and processing units. The orchard should be protected from high wind velocity to create favorable microclimate. Wind breaks consist of planting of trees, shrubs or raising of artificial barriers on the windward side of an orchard for protection from wind. The most effective windbreak is a double row of tall trees, alternately placed. In the space between wind break trees, a hedge of karonda, phalsa may also be planted.

The fruit plants raised in the nursery are generally used to establish new orchards. For success in dry lands, plants must have root architecture with a strong tendency to penetrate deep into the soil. Sometime plants raised in nursery beds or containers become soil or pot bound respectively and loose potential tap root during the process of plant lifting. Therefore, in-situ technique of orchard establishment is found suitable under arid and semi-arid conditions (Nath et al. 2000). In this method, seeds of root stock species are sown right there on the field at the recommended spacing during the month of July with the onset of monsoon. The rootstock plants raised in this manner develop deep tap root system and hence they have more drought resistance. The seedlings are protected till next summer and when they attain pencil size thickness in monsoon, budding with suitable scion cultivars or elite genotype is done. This technique is found most suitable for the crops like ber, jamun, bael, gonad, wood apple, custard apple and aonla. Among the fruit tree species two methods of planting (i.e., auger hole and pit methods) were tested using 5 and $10 \mathrm{~kg}$ of gypsum in each auger hole and 10 and $20 \mathrm{~kg}$ of gypsum in each pit as soil amendments. After seven years ber, jamun, guava, aonla and karonda were the successful species for these soils showing good growth and also initiated fruit setting in semi-arid alkali-sodic Soils of Haryana, India (Dagar et al. 2001). The soil moisture content in the pit planting $30 \mathrm{~cm}$ in depth $(30 \mathrm{~cm}$ pit planting) and $50 \mathrm{~cm}$ in depth $(50 \mathrm{~cm}$ pit planting) was at least 1.3 times higher than that of the control plot i.e. surface planting (Jo \& Prank 2017). Innovative orchard establishment method for minimizing drought and edaphic stresses in fruit crops grown in shallow basaltic soils of semi-arid region was standardized by NIASM, Baramati, Maharashtra (Minhas et al. 2015). In the medium rainfall region of eastern Uttar 
Pradesh, application of FYM, pond soil, gypsum, and pyrite in sodic soils resulted in better establishment and growth of aonla and bael plants (Sharma et al. 2013).

\section{Planting density}

The plant density mainly depends upon the plant type, soil fertility, varieties, growth habit of tree, rootstock used and management practices play important role in deciding optimum spacing in an orchard. Accordingly different systems of planting viz., square, rectangular, triangular (alternate), quincunx, hexagonal, contour and hedgerow system of planting may be chosen. Generally, adjacent planting is followed in arid regions and in poorly fertile soils. In this system two plants are placed closely keeping double space between rows (Radha and Mathew, 2007). In the plains, planting, is generally done in square or rectangular system while on slopy lands, fruit trees are planted on contour terraces, half moon terraces, trenches and bunds, and micro-catchments. On marshy and wet areas mounding and ridge-ditch method of planting have been suggested. The trenches and bunds made across the slope are staggered (Saroj et al., 1994). In a micro-catchment, which may be triangular or rectangular, trees are planted at the lowest point where runoff accumulates. In a micro-catchment, which may be triangular or rectangular, trees are planted at the lowest point where runoff accumulates (Shrma et al., 2013). The planting distance $6 \times 6 \mathrm{~m}$ or $8 \times 8 \mathrm{~m}$ for ber cultivation is optimum. Date palm, bael and aonla are planted at $8 \times 8 \mathrm{~m}$ or $10 \times 10 \mathrm{~m}$ distance (Table 5).
Table 5. Recommended spacing for different fruit crops of arid and semi-arid regions

\begin{tabular}{lcc}
\hline Crop & Spacing (m) & $\begin{array}{c}\text { No. of } \\
\text { plants ha }\end{array}$ \\
\hline Kinnow & $6 \times 6$ & 277 \\
mandarin & $5 \times 5$ & 400 \\
Acid lime & $5 \times 5$ & 400 \\
Guava & $4 \times 4$ & 625 \\
Pomegranate & $5 \times 5$ & 400 \\
Date palm & $2 \times 2$ & 2500 \\
Phalsa & $6 \times 6$ & 277 \\
Ber & $4 \times 4$ & 625 \\
Karonda & $8 \times 8$ & 156 \\
Aonla & $6 \times 6$ & 277 \\
Lasoda & $6 \times 6$ & 277 \\
Fig & $6 \times 6$ & 277 \\
Mulberry & $8 \times 8$ & 156 \\
Bael & $6 \times 6$ & 277 \\
Gonda & $5 \times 5$ & 400 \\
Sweet orange & planting & studies in
\end{tabular}

High density planting studies in pomegranate revealed that the maximum plant height was recorded at $2 \times 2 \mathrm{~m}$ spacing, whereas plant height, stem girth, average number of fruits, average weight of fruit and yield was obtained under $4.5 \times 3.0 \mathrm{~m}$ spacing under Rahuri conditions (Anon. 2013). High density planting is also beneficial in aonla (Singh et al. 2010, Singh et al. 2018) and ber, bael, chironji (Singh et al. 2016) and jamun (Singh et al. 2018) fruit trees to achieve high yield under semi-arid conditions.

After completion of layout, the pits of convenient size $\left(60 \mathrm{~cm}^{3}\right.$ or $\left.1 \mathrm{~m}^{3}\right)$ are dug at required spacing, one month before planting. Afterwards, the pits are filled with $40-50 \mathrm{~kg}$ of 
well rotten FYM or compost, $2 \mathrm{~kg}$ vermicompost, $2 \mathrm{~kg}$ oil cakes and $25.50 \mathrm{~g}$ Trichoderma powder along with top soil. This operation is performed 10-15 days before transplanting. The pits are drenched with imidacloprid-17.8\% SL to avoid termite attack. In general, grafts or seedlings along with earth ball are planted in monsoon season. Care should be given so that the bud/graft union is kept well above the soil level. Immediately after planting, copious watering should be applied to establish and start new growth. New transplants should be supported with stakes to avoid falling on the ground and to direct the erect growth. Other immediate operations after planting of fruit trees are preparation of basin, manuring, gap filling, protection from frost or sun scorching, removal of stock sprouts, plant protection measures etc.

\section{After care of young plants}

* The newly planted young fruit plants, being very tender need lot of care and attention for their better survival and growth.

* The plant should be watered at regular intervals, however heavy irrigation should be avoided.

* The young plants need staking so as to make them grow upright and straight.

* Young plants needs to be examined on regular basis and at the same time all the new growth taken place below the bud union are removed.

* The tying materials still tied at the graft union should be removed carefully.

* Training of young plants should be given utmost attention for developing proper framework and shape. Remove dead and diseased portion by careful pruning.

* The young plants should always be protected against diseases and insects by proper and timely sprays of suitable fungicide/insecticides.

* Nitrogenous fertilizers should always be given in small split doses to young fruit trees.

* Provide adequate protection against vagaries of summer and winter season.

\section{Moisture conservation and mulching}

Water being a scarce commodity in arid eco-system, the first and foremost requirement is to conserve the available soil or rain water. For conservation of rain water both in-situ and ex-situ technologies need to be adopted. Rainwater harvesting can help in supplying enough water to improve plant establishment and crop yield. Microcatchment is one of the direct water harvesting system where small structures are constructed across land slopes which captures surface runoff and stores in plant root zone for subsequent use by the plant (Ali et al. 2017). It has been observed that the micro-catchment slopes greater than 5\% did not significantly affect run off at Jodhpur. The highest ber yield was obtained when $0.5 \%$ and $5 \%$ slopes had $8.5 \mathrm{~m}$ and $7.0 \mathrm{~m}$ length of run, and $72 \mathrm{~m}^{2}$ and $54 \mathrm{~m}^{2}$ catchment areas per tree, respectively (Sharma et al. 1986).

Effective moisture conservation practice also includes various types of Mulching material. Goode and Hyryoz (1968) reported that mulches increase the soil and water content under intermittent rain or irrigation. Generally, organic and inorganic mulches are commonly used to conserve soil 
moisture. Mulching helps in maintaining soil temperature and moisture, avoiding weed competition, improving soil structures and biological activities, resulting into increased crop yield. In addition, the use of organic materials as mulch can enhance soil fertility, structure and other soil properties (Singh et al. 2016; Sarolia \& Bhardwaj 2012). Paddy straw mulch was found suitable for aonla crop to improve production under semi-arid conditions of Gujarat (Singh et al. 2010). When compared to other mulches plastic mulches are completely impermeable to water; it therefore prevents direct evaporation of moisture from the soil and thus limits the water losses. In this manner, it plays a positive role in water conservation. Under arid condition it is reported that, organic mulches like grasses, weeds and crop residues reduce the soil temperature considerably during summer months, while during winter months clear/ transparent plastic mulch increase soil temperature. Black polythene mulch as well paddy straw mulch both are found very effective in initial plant establishment and improved plant growth of pomegranate, acid lime and guava ber orchards in western India.

The quality and efficiency of water management determine the yield and quality of fruits. Water demand is a function of weather conditions, crop species and variety, stage of growth, soil water retention capacity and texture and irrigation system management. If water is scarce and supplies are erratic, then irrigation at critical stage and soil moisture conservation are the most important agronomic interventions to maintain yields during stress. Among the different systems, drip irrigation is an efficient tool of water application in most of fruit crops. In this system water is delivered through drippers directly to the soil adjoining to the root system, which absorb the water immediately. Studies indicate that drip irrigation could save water from 33 to $55 \%$ with yield increase to a tune of $50 \%$ or more besides improving the quality of the produce in different fruit crops. Fertilizers and pesticides can also be delivered with drip irrigation system to the crops and thus minimizes their application losses. Most importantly, their split application can be made as per the requirement at different crop stages. The use of drip alone or in combination with mulching has been demonstrated as a successful technology for cultivation of pomegranate, kinnow, date palm etc. (Sharma et al. 2013). Sharma et al. (2013) also emphasized the application of pitcher irrigation as water conservation approach for better establishment of fruit plants in dryland areas. It was attempted in cactus pear at CIAH, Bikaner, and the growth of cactus pear was better as compared to control. This technology can be used to establish other fruit crops too.

Water loss caused by transpiration can be reduced by use of radiation reflectants, stomata closing chemicals, and plastic films. Spraying of 4 to $6 \%$ kaolin, $0.5-1.0 \%$ liquid paraffin, and $1.5 \%$ power oil, after occasional rains in low rainfall areas, considerably reduces plant water losses (Pareek \& Sharma 1991). Chemicals such as phenyl mercuric acetate (PMA), decinyl succinic acid (DSA), abscisic acid (ABA), and acetylalcohol cause stomatal closure thereby reducing 
transpiration (Jones and Mansfield, 1991). Shelterbelt and windbreaks can reduce evapotranspiration by reducing the wind speed and stabilizing microclimate (Muthana et al. 1984).

\section{Weed control}

Weed control is important in dry land orchards in order to reduce soil moisture losses and improving plant growth. Timely weeding is essential to improve plant growth even in high rainfall areas. Application of preemergence weedicides such as nitrofen, bromacil @ 2-3 kg and post emergence as glyphosate and paraquat @ 1.0 litre per hectare have proved effective in checking weed growth in the orchards.

\section{Nutrient Management}

Soils of arid and semi-arid regions are poor in organic matter that affects nutrient use efficiency as well as soil moisture retention (Singh et al., 2016). Fruit plants are nutrient exhaustive crops and deplete soil fertility extensively thus necessitates the judicious application of fertilizers. The balanced nutrition in fruit plants is required at appropriate time according to the age of plants. The application methods also play important role for availability of nutrients to the plants. In ber orchards, besides 10-15 kg organic manure, annual application of $100 \mathrm{~g}$ $\mathrm{N}, 50 \mathrm{~g} \mathrm{P}_{2} \mathrm{O}_{5}$ and $50 \mathrm{~g} \mathrm{~K}_{2} \mathrm{O}$ per tree is recommended. Fertilizer doses should be raised according to the age of plants and soil fertility of the region. Application of $15-20 \mathrm{~kg}$ FYM per tree has been found beneficial in aonla, custard apple, and tamarind. At MPKV, Rahuri, in addition to $50 \mathrm{~kg}$ FYM, $625 \mathrm{~g} \mathrm{~N}$, $225 \mathrm{~g} \quad \mathrm{P}_{2} \mathrm{O}_{5}$ and $225 \mathrm{~g} \quad \mathrm{~K}_{2} \mathrm{O}$ has been recommended for application to 5-year-old pomegranate trees. In 6 to 7 -year-old fig trees planted at $5 \mathrm{~m} \times 5 \mathrm{~m}$ spacing, fertilization with $900 \mathrm{~g} \mathrm{~N}+250 \mathrm{~g} \mathrm{~K}$ improved fruit production (Sharma et al. 2013).

Organic fertilization can improve fruit crop tolerance to soil stresses like salinity, drought, alkalinity and excessive amounts of toxic elements. A number of studies have shown that the organic manure application increases water as well as nutrient use efficiency of soil due to increased organic matter content and other soil physical, chemical and biological properties which in turn favours better plant growth and development that help in counteracting the adverse conditions near rhizosphere. Foliar application of nutrients has been also recommended as a means of improving plant growth especially in the early stages of development as it provides the required nutrient directly to the location of demand in the leaves and results in rapid absorption, being independent of root activity and soil water availability. Vermicompost gained popularity due to recent interest in organic farming and is mostly used in fruit crops. It is rich source of micro and macronutrients, vitamins, growth hormones and enzymes. Organic content was found to be significantly higher with the application of FYM and vermicompost, while bulk density was decreased. In recent past use of different grade water soluble fertilizer through drip has been increased due to its improved fertilizer use efficiency and plant growth, yield and quality of produce. Micronutrients are often found deficient in semi-arid and arid soils and play significant role in production of high grades fruits. Foliar feeding of nutrients such as 
nitrogen (0.5-2.0\% urea), zinc (0.05-1.0\% zinc sulphate) and boron (0.05-1.0\% borax) has given beneficial results in these areas (Pareek \& Sharma 1991).

\section{Pests and disease management}

Besides insects and diseases, wild animals, rodents and birds also cause loss to the horticultural crops. Major insect-pests and diseases of arid fruit crops and their control measures are presented in Table 6 (Sharma et al. 2013; Haldhar et al. 2019). Apart from this should be follow good agricultural practices (GAPs) and IPM approaches for managing the insect-pest level below the economic threshold limit (ETL). Possible practices/ approaches may be summer ploughing, soil solorization, removal of dead woods followed by buried or burn, pasting of stem, sanitize all implements /equipments, weeding/ hoeing, use of bird net/bird scaring ribbon, use of yellow stick/pheromone/ light traps as well as bio/organic botanicals etc.

Table 5. Major pests and diseases and their control measures

\begin{tabular}{|c|c|c|}
\hline Crops & Pests/diseases & Control measures \\
\hline \multirow[t]{3}{*}{ Ber } & $\begin{array}{l}\text { Fruit fly (Haldhar et al. } \\
\qquad 2018 \mathrm{a})\end{array}$ & $\begin{array}{l}\text { Combined operation of soil digging and mixing of } 50 \\
\mathrm{~g} \text { insecticidal dust (Thiodicarb-75\%WP), spray of } \\
\text { Quinalphos-25\%EC }(1.5 \mathrm{ml} / \mathrm{l}) \text { or Spinosad- } 45 \% \mathrm{SC} \\
(0.01 \%) \text { in rotation. }\end{array}$ \\
\hline & $\begin{array}{l}\text { Weevil (Haldhar et al. } \\
\qquad 2018 b \text { ) }\end{array}$ & Spray of Indexocarb $0.5 \mathrm{ml} / 1$ control the weevil \\
\hline & $\begin{array}{l}\text { Termite (Haldhar et al. } \\
\text { 2016) }\end{array}$ & Drenching with Clothiandin 50 WDG $1 \mathrm{ml} / 1$. \\
\hline \multirow[t]{2}{*}{ Pomegranate } & Mites & $\begin{array}{l}\text { Spray of Propargite } 57 \%(1 \mathrm{ml} / 1) \text { or Dicofol } 18.5 \mathrm{EC} \\
\qquad(2 \mathrm{ml} / \mathrm{l}) \text { in rotation. }\end{array}$ \\
\hline & $\begin{array}{l}\text { Thrips } \\
\text { Aphid }\end{array}$ & $\begin{array}{l}\text { Spray of Imidachloprid }(0.2 \mathrm{ml} / \mathrm{l}) \text {. } \\
\text { Spray of Imidachloprid }(0.3 \mathrm{ml} / \mathrm{l}) \text { or Thiomethoxam } \\
(0.40 \mathrm{ml} / \mathrm{l}) \text { at the time of new growth. }\end{array}$ \\
\hline \multirow[t]{2}{*}{ Aonla } & $\begin{array}{l}\text { Fungal spots and rots } \\
\text { Leaf gall midge }\end{array}$ & $\begin{array}{c}\text { Mancozeb }(0.2 \%)+\text { Carbendazim }(0.20 \%) \\
\text { Spray of Quinalphos-25\%EC }(1.5 \mathrm{ml} / 1)\end{array}$ \\
\hline & Rust & Spray of Chlorothalonil $(0.2 \%)$ at 10 days interval. \\
\hline Bael & $\begin{array}{l}\text { Leaf eating cater pillar } \\
\text { (Haldhar et al. 2010) }\end{array}$ & $\begin{array}{c}\text { Spray of Quinalphos-25\%EC }(1.5 \mathrm{ml} / \mathrm{l}) \text { or } \\
\text { Imidachloprid }(0.3 \mathrm{ml} / \mathrm{l})\end{array}$ \\
\hline \multirow[t]{2}{*}{ Date palm } & $\begin{array}{l}\text { Scale insect (Haldhar } \\
\text { et al. 2017) }\end{array}$ & Spraying of Quinalphos-25\%EC (1.5ml/1). \\
\hline & Graphiola leaf spot & Spray of Bavistin $(0.1 \%)$ or Blitox-50 WP $(0.4 \%)$ \\
\hline Fig & Rust & Two spray of Mancozeb (0.3\%) is effective. \\
\hline
\end{tabular}




\section{References}

Ali SM, Bai K, Hanumantharaya BG \& Nagraj KH. 2017. Micro-Catchment Techniques: An Effective Water Conservation Practice in Mango. Int.J.Curr.Microbiol.App.Sci., 6 (5): 2965-2969.

Anonymous. 2013. Annual Report of Research Workers Meet of AICRP on Arid Zone Fruits, held at M PKV, Rahuri (MS), p:183.

Dagar JC, Singh G \& Singh N T. 2001. Evaluation of forest and fruit trees used for rehabilitation of semiarid alkali-sodic soils in India. Arid Land Research and Management, 15(2):115-133.

Goode JE \& Hyryoz KJ. 1968. The response of malling jewel and malling exploit rasp berries to different soil moisture conditions and straw mulching. Journal of Horticulture Science, 45 (3): 379-391. Haldhar SM, Bhargava R, Krishna H, Berwal MK \& Saroj PL. 2018a. Bottom-up effects of different host plant resistance cultivars on ber (Ziziphus mauritiana)fruit fly (Carpomyia vesuviana) interactions. Crop Protection, 106: 117124.

Haldhar SM, Chet Ram \& Singh D. 2019. Biotic stress (insect) of aonla (Emblica officinalis) in arid region of India: a review. Journal of Agriculture and Ecology, 7: 16-26.

Haldhar SM, Deshwal HL, Jat GC, Berwal MK \& Singh D. 2016. Pest scenario of ber (Ziziphus mauritianaLam.) in arid regions of Rajasthan: a review. Journal of Agriculture and Ecology, 1: 10-21. Haldhar SM, Karuppaiah V, Sharma SK \& Singh RS. 2010. Population Dynamics of Lemon Butterfly (Papilio demoleus) in Bael [Aegle marmelos] as Influenced by Abiotic Factors in Arid Region of Rajasthan. Indian Journal of Arid Horticulture. 5 (1-2): 50-52.

Haldhar SM, Maheshwari SK \& Muralidharan CM. 2017. Pest status of date palm (Phoenix dactylifera) in arid regions of India: a review. Journal of Agriculture and Ecology, 3: 1-11

Haldhar SM, Singh AK, Kumar K \& Sarolia DK. 2018b. Antixenotic and allelochemical resistance traits of ber (Ziziphus mauritiana) against stone weevil, Aubeus himalayanus in hot arid region of India. Indian Journal of Arid Horticulture, 13: 50-58.

Joa Hyun-Kil \& Hye-Mi P. 2017. Effects of pit plantings on tree growth in semi-arid environments. Forest Science and Technology, 13(2):66-70.

Jones RJ \& Mansfield TA. 1971. Antitranspirant activity of the methyl and phenyl esters of abscisic acid. Nature, 231: 331-332.

Minhas PS, SinghY, Nangare DD \& Kumar PS. 2015. Establishing orchards in shallow soils. Indian Horticulture, NovDec., pp:5-8.

Mishra DS, Singh S, Singh AK \& Yadav V. 2016. Future fruit crops for semi-arid conditions of western India. In: Lakhawat, S.S. (ed.) Exploitation of underutilized fruit crops of arid and 
semi-arid region, MPUAT, Udaipur,pp: 187-192.

More TA, Singh RS, Bhargava R \& Sharma BD. 2012. Arid-Horticulture for Nutrition and Livelihood. Agrotech. Publishing Academy, Udaipur, p :376.

Nath V, Saroj PL, Singh RS, Bhargava R \& Pareek O P. 2000. In-situ establishment of ber orchards under hot arid ecosystem in Rajasthan. Indian Journal of Horticulture, 57(1): 21-26

Nath V., Kumar, D. and Pandey, V. 2008. Introduction. In: Fruits for the future, Vol 1: Well versed Arid and Semi Arid Fruits, Satish Serial Publ. House, 403, Express Tower, Commercial Complex, Azadpur, Delhi, PP. 1-18.

Pareek OP \& Sharma S.1991. Fruit trees for arid and semi-arid lands. Indian Farming, 41: 25-30.

Radha T\&Mathew L. 2007. Orchard planning, layout and management. In: K.V. Peter (Ed.) Fruit crops. NIPA, New Delhi, pp.7-19.

Richards LA. 1954. Diagnosis and improvement of saline and alkali soils. Agriculture Handbook no. 60, USDA, Washington, D.C.

Samadia DK \& Haldhar SM. 2017. Breeding strategies and scope of improvement in arid zone fruit crop-plant under abiotic stressed agro-climate: an analysis. Journal of Agriculture and Ecology, 4: $1-13$.

Saroj PL, Dubey KC \& Tewari RK. 1994. Utilization of degraded lands for fruit production. Indian Journal of Soil Conservation, 22: 162-176.
Saroj PL. 2018. Global scenario of fruit production in arid and semi-arid regions for combating hunger. In: P.L. Saroj et al. (Eds.) Proceedings of National Conference on Arid Horticulture for Enhancing Productivity and Economic empowerment (27-29 Oct., 2018), ICAR-CIAH, Bikaner, pp: 1-15.

Saroj PL. 2018a. Exploiting potential of arid horticulture. Indian Horticulture, 63(5):3-16.

Sarolia DK \& Bhardwaj RL. 2012. Effect of mulching on crop production under rainfed condition: a review. International journal of Research in chemistry and environment, 2 (2):8-20.

Sharma KD, Pareek OP \& Singh HP. 1986. Micro-catchment water harvesting for raising jujube orchards in arid climate. Trans. ASAEI, 29: 112-118.

Sharma S, Singh RS \& Bhargava R. 2013. Arid horticulture: an overview. Annals of Arid Zone, 52(3\&4): 251-264.

Singh AK, Singh S, Apparao VV, Meshram DT, Bagle BG \& More TA. 2010. High Density Planting Systems in Aonla, CIAH Tech. Bull. No. 34., CIAH, Bikaner p: 15.

Singh AK, Singh S, Mishra DS \& Saroj PL. 2016. In rainfed semi-arid region: More crop with minimal water. Indian Horticulture, 61(6):86-91.

Singh AK, Singh S, Mishra DS \& Saroj PL. 2018. Aonla for economic and health security in drylands. Indian Horticulture, 63(1):36-40.

Singh S, Singh AK, Mishra DS \& Appa Rao VV. 2018. High density planting in 
jamun doubles the farmers' income. Indian Horticulture, 63(3):14-16.

Singh S, Singh AK, Mishra DS \& Appa RaoVV. 2018. Technological intervention in arid and Semi-arid fruits for enhancing farm income. In: Souvenir of National Conference on Arid Horticulture for Enhancing Productivity \& Economic Empowerment (Saroj, P.L., Bhargawa, Sharma, B.D., Singh, D. and
Singh, S. eds.) held at ICAR-CIAH, Bikaner, pp: 57-60.

Tiwari AK, Mishra DS, Kumar S \& Champathi Gunathilake DMC. 2018. Exploitation of climate resilient minor tropical fruit crops for nutritional and livelihood security in Fiji Islands. Int. J. Curr. Microbiol. App. Sci., 7(11): 21352142. 